\title{
Evaluation of five pearl millet ecotypes susceptibility to the nymphal instars of migratory locust
}

\author{
KHOLDI FATHI SALIM GOMAA ${ }^{1}$, MAGZOUB OMER BASHIR ${ }^{2, \bullet}$ \\ ${ }^{1}$ College of Graduate Studies, Sudan University of Science and Technology, Sudan \\ ${ }^{2}$ Department of Crop Protection, Faculty of Agriculture, University of Khartoum, Shambat, Sudan. vemail: yamagzoub2@yahoo.com
}

Manuscript received: 11 March 2017. Revision accepted: 29 June 2017.

\begin{abstract}
Gomaa KFS, Bashir MO. 2017. Evaluation of five pearl millet ecotypes susceptibility to the nymphal instars of migratory locust. Trop Drylands 1: 57-63. African migratory locust (Locusta migratoria migratorioides) is among the most devastating pests in African dry land, threatening the sustainability of agricultural crops including the pearl millet (Pennisetum glaucum). This study aimed to investigate the susceptibility of five ecotypes of pearl millet to the nymphal instars of the solitary African migratory locust and to detect the most preferred millet variety. The experiments were undertaken under semi-field (cage-experiment) conditions. Five different experiments with five ecotype varieties of pearl millet Pennisetum glaucum var. were setup. Each experiment with three replications was applied topically on the $3^{\text {rd }}$ and $4^{\text {th }}$ nymphal instars. The food preference and ecotype susceptibility evaluation were based on the amount of food intake in grams, weight of food ingested and digested in gram, percentages, and amount of weight of feces in gram. The results showed a significant difference in susceptibility of five ecotypes of pearl millet. The susceptibility of feeding by $3^{\text {rd }}$ and $4^{\text {th }}$ nymphal instars was observed in all ecotypes. The study results showed that the preference of ecotypes by nymphs was increased according to increasing application time. The highest one was Bayouda-late maturing compared to four other ecotypes. During the experiments, we noticed that the preferences of five ecotypes were elevated in the first and third readings of experiments. However, we discovered in the study that the susceptibility of five pearl millet ecotypes was according to the remaining amount of feces in any ecotype variety. The least amount of reminder feces was in Bayouda-late maturing ecotype, which means that most of the food intake was ingested, digested and assimilated as with the four other ecotypes. The greater percentages of ingested amount of food consumption for five ecotypes of pearl millet, with $3^{\text {rd }}$ and $4^{\text {th }}$ instars of African migratory locust, ranked as mentioned above. The research concludes that further works on evaluation of susceptibility of pearl millet varieties with different pests, particularly in migratory locust is recommended to detect the palatable target variety as a trap in pest management control.
\end{abstract}

Keywords: Pennisetum glaucum, ecotypes, nymphal instars, migratory locust

\section{INTRODUCTION}

Locusts belong to a large group of insects commonly called short-horned grasshoppers within the superfamily Acridoidea, and the most important locusts are all in the family Acrididae (Anonymous 1966). They differ from grasshoppers in their behavior and phase of transformation. An important feature of locusts is their ability to transform reversibly between the two extreme phases of solitaria and gregaria which differ in morphology, physiology, and behavior (Uvarov 1966). Gregarious locusts have the tendency to stay together in dense groups, march in bands as wingless hoppers or adult swarms over long distances (Steedman 1988).

Locusts are considered among the major pests in the Sahel zone of Africa. The migratory locust Locusta migratoria (Reiche and Farmaire) belongs to a monospecific genus of Locusta Linnaeus. Migratory locust is one of the most important destructive agricultural pests in the world, and its outbreaks were recorded early in the $13^{\text {th }}$ century BC (Fan 1983; Vijay et al. 2013). Migratory locust is a highly migratory species with a greater distribution in temperate and tropical regions of the eastern hemisphere (Asia, Europe, Africa and Australia) and was also found to present up to $4600 \mathrm{~m}$ above sea level in the Tibet Plateau (Guo et al. 1991; Meinzingen 1993).
Previous studies (Uvarov 1921, 1977) reported that $L$. migratoria also has significant phase polymorphism ability including changes in their morphology, physiology, and behavior with transitory morphs between solitarious to gregarious phases or vice versa. Both nymphs and adults of the locust exhibit density-dependent phase polymorphism and they also have cryptic body coloration at low-density conditions. This body coloration includes green, orange, brown, or black and is sedentary in nature. At low density, the locust also shows little or no tendency to aggregate. Besides having morphological changes, however, when their population density increases then both nymphs and adults show strong tendency for aggregation and dispersion. Nymphs march in bands on ground while adults form swarms and migrate over long distances, sometimes several hundred kilometers (Uvarov 1977).

Traits change in morphology, coloration, physiology, and behavior in the migratory locust and its wide distribution lead to identification of different species of this species. Thus, this species was differently named as $L$. australis, L. danica, L. gallica, L. rossica, and L. solitaria. Seven subspecies within Locusta migratori that are recognized at present are $L . m$ burmana, $L . m$ capito, $L . m$ cinerascens, $L . m$ migratoria, L. $m$ manilensis, $L . m$ migratorioides, and L. $m$ tibetensis (Zhang et al. 2009). Some studies have identified differentiations among 
various populations of $L$. migratoria and three genetically different groups viz L. m migratoria, $L$. $m$ manilensis, and L. $m$ tibetensis. Dispersal routes of the migratory locust show that global populations can be divided into two different lineages, the northern lineage, and southern lineage.

The outbreak of L. migratoria has caused severe damage to the pasture land and agriculture besides terrifying people and causing traffic accidents by the swarming locusts (Kumar and Ramamurthy 2009). Summer breeding takes place in eastern Sudan especially in Elgedaref state, Gezira State, Sinar State, Blue Nile State, Northern State and River Nile State (Hamid 2003).

Millet (Pennisetum glaucum L.) is one of the preferred cereals besides the wheat, rice, and maize attacked by the pest. Millet is a major food source for millions of people, especially those who live in hot, dry areas of the world. It is grown mostly in marginal areas under agricultural conditions in which major cereals fail to give substantial yields (Adekunle 2012). Millet is classified with maize, sorghum, and Coix (Job's tears) in the grass subfamily Panicoideae (Yang et al. 2012). Millet is an important food in many underdeveloped countries because of its ability to grow under adverse weather conditions such as limited rainfall. Millet is the primary source of energy and protein for millions of people in Africa. Previous studies reported that millet has many nutritious and medical attributes (Obilana and Manyasa 2002; Yang et al. 2012). Millet is a drought-resistant crop and can be stored for a long time without insect damage (Adekunle 2012); hence, it can be important during famine.

Millets are unique among the cereals because of their richness in calcium, dietary fiber, polyphenols and protein (Devi et al. 2011). Millets contain significant amounts of essential amino acids particularly the sulfur-containing amino acids (methionine and cysteine); they are also high in fat content than maize, rice, and sorghum (Obilana and Manyasa 2002). They provide fatty acids, minerals, vitamins and typical millet protein contains high quantity of essential amino acids (FAO 2009).

However, millets are subjected to many insect pests, and the most dangerous ones are locusts. The locust concentrations are often found to be associated with particular species of food plants. Among the cultivated crop, we discovered a close association between locust and millet crop which might be due to the type of variety and cropped area, ecotype, or other factors. There are more than five varieties of Pennisetum glaucum in the Darfur region, Sudan but these five varieties are frequently found in the locust habitat. An advantage of testing this ecotype is that it is possible to know the preferred variety, which will make the survey of locusts more limited. Knowing the preferred variety will be very cost-effective as well as time and effort saving. It will also help to suggest and detect any gregarisation that may happen. It is better to control the locust before they swarm and migrate as it may be too late to stop the damage they cause.

This study investigates and evaluates the susceptibility of five ecotypes of Pearl millet (Pennisetum glaucum) to the nymphal instars of the solitary African Migratory
Locust Locusta migratoria migratorioides and detects the most preferred millet variety.

\section{MATERIALS AND METHODS}

We carried out this study under laboratory and semifield conditions at the Biological Control Unit of Insectary Laboratory, Department of Crop Protection, Faculty of Agriculture, University of Khartoum, Shambat, Sudan during the period from May 2014 to December 2014 (Temp. $22^{\circ} \mathrm{C}-39^{\circ} \mathrm{C}$, R.H 17-19\%, and normal daylight).

\section{Rearing of migratory locust}

The culture (Figure 1) was started from the initial material (nymphs and mature adult individuals of the migratory locust obtained from eastern part of Sudan, Elgedarif State (Elmaganez District) which lies on Latitude N 143114.4 and Longitude E 03512 45.0. Two hundred individual nymphs and mature adult locusts of male and female were used to start the mass rearing. The new hatches were reared up to the second generation to ensure the homogeneity of the population. The third and fourth instars were then used as the experimental insects.

\section{Rearing and egg-laying cages}

The rearing cage was made of mosquito wire mesh sides; the bottom was made of plywood. It measured $70 \mathrm{~cm}$ $\times 60 \mathrm{~cm} \times 50 \mathrm{~cm}$. One side of the cage was covered with a light cloth in the form of a sleeve to facilitate the easy handling of insects to perform various activities inside the cage such as feeding and cleaning without the insects being able to escape from the cage. On the bottom surface of the cage, six holes were made for fixing plastic cups, filled with a wet mixture of sandy clay soil (3:1). These cups were used to provide sites for egg laying. The insects were fed on millet and fresh sorghum fresh leaves, and wheat bran. The rearing-egg laying cage was cleaned daily from insect fecal pellets, with a brush. The insects were monitored, and various activities of mature adults including soil probing, copulation, and egg-laying were observed. After the eggs had been laid, the cups which contained sufficient egg pods were removed and replaced by new ones, using gloves to protect hands and mask to avoid odors. The cups containing the egg pods were covered with cheesecloth and the soil periodically moistened until egg hatching. The hatched nymphs were reared up to the $3^{\text {rd }}$ and $4^{\text {th }}$ instars, which were used in the experiments.

\section{Hoppers rearing cage}

The hoppers rearing cage measured $40 \mathrm{~cm}$ x $30 \mathrm{~cm}$ x 30 $\mathrm{cm}$ (Figure 2) was made of wood and mosquito wire net on four sides. The fifth is side made of light cloth fitted with a zip fastener, in the form of a strip. This zipper was made to facilitate carrying out the activities of feeding and cleaning by hand inside the cage, without the insects being able to escape away from the rearing cage. 


\section{Food materials}

Five varieties of millet plants were brought from the Darfur State. These five ecotype varieties included: (i) Early Bayouda is dark gray, medium and strong in seeds, it is grown in North Darfur, Saraf Omra area in cracked clay soil. (ii) Late Bayouda is slightly yellow, long stack, large and strong and has conveyed seeds, grown in cracked clay soil in Jebal Mara. (iii) Wad Elahow late-maturing is yellowish and spherical seeds, long plant; it is grown in south of Nyala semi cracking clay soil. (iv) Kano is slight gray small seeds, long plant; it is grown in cracking loamy clay soil southwest of Nyala. and (v) Dembi is relatively a dwarf short day to maturity, a red seeded variety grown in North Darfur Shangil Toobaya area. The taller, longerseason and white-seeded type have different names in different places (Abuelgasim 1989; Sabil 1991; Abuelgasim 2011).

These five ecotypes were grown in ground basins of $200 \mathrm{~cm} \times 100 \mathrm{~cm}$. Millet seedlings of the five varieties were grown in plastic cups to provide daily feed to the nymphs and adults (Figure 3). Also, wheat bran was provided for additional supplementary feeding. The cages were checked daily for cleaning and provision of food. Adult locusts that emerged were transferred to egg-laying cages.

\section{Experimental cages}

The cages used in the tests were made of wood and wire mesh. Each cage measured $25 \mathrm{~cm} \times 25 \mathrm{~cm} \times 30 \mathrm{~cm}$ (Figure 4). Millet was provided as food for the treated migratory locust. The insects were treated topically and then released into the cages.

\section{Food preference experiments (feeding tests)}

Five varieties or ecotypes of Millet plant were sown in five different ground basins. Then after emerging and during shooting period, before application experiments, 20 grams of fresh plant shoot were weighed and dried for later parameters calculation. The plant shoots were weighed using a sensitive balance and then placed inside the cages which contained twenty nymphs which were considered as an experimental replication unit. The experiment was arranged in a completely randomized design (CRD) and factorial experiment (FE) with three replications. The feeding rate of the five millet plant ecotypes and survival of the tested insects were used as parameters to evaluate preference.

The weight of food consumption (food intake) of each ecotype fed by hoppers ( $3^{\text {rd }}$ and $4^{\text {th }}$ instars) was recorded after $24 \mathrm{hrs}, 48 \mathrm{hrs}$ and $72 \mathrm{hrs}$ for each experiment. The weights of fecal pellets in all cages for three days were also recorded. The parameters (ingested food, assimilated food, fecal pellets and their percentages) were calculated using the following equations:

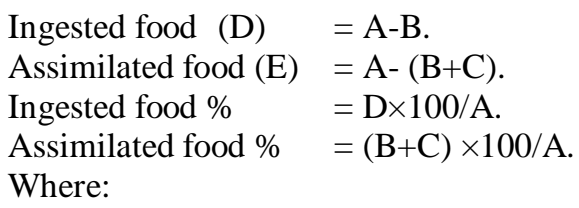

A: Wet weight of shoot amount. B: Spill, C: Feces

\section{Statistical analysis}

This study was assigned in a factorial experiment laid out in a Completely Randomized Design (CRD). The first factor was pearl millet ecotypes (five ecotypes/varieties) and the second was time of observation $(24 \mathrm{hrs}, 48 \mathrm{hrs}$, and $72 \mathrm{hrs}$ ). The obtained data were analyzed according to SAS program version 3, SAS 1997. The accepted level of significance was $\leq 0.05$ and differences between the treatment means were detected using the least significant difference (LSD) according to Gomez and Gomez (1984).

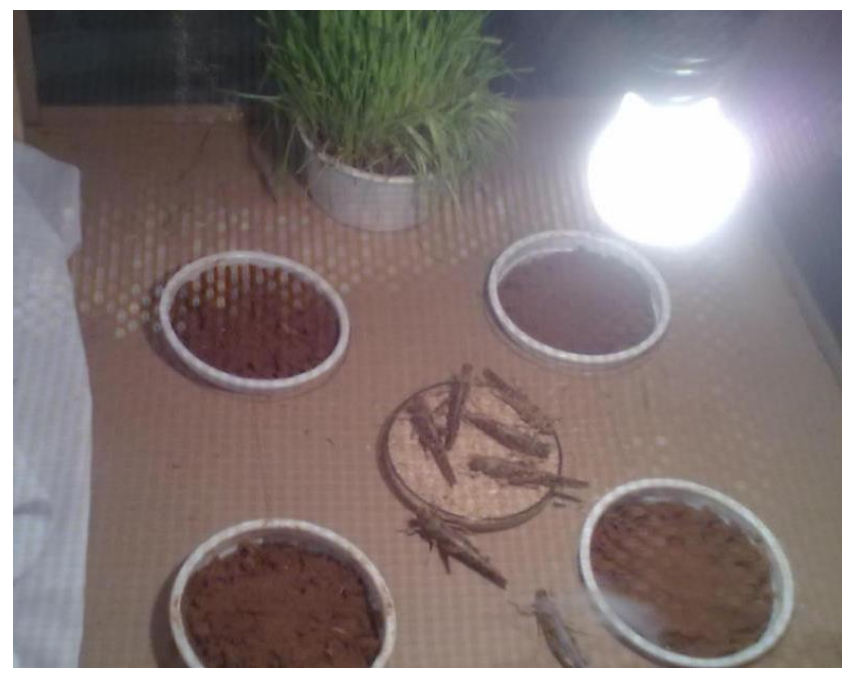

Figure 1. Oviposition unit setup for rearing of migratory locust

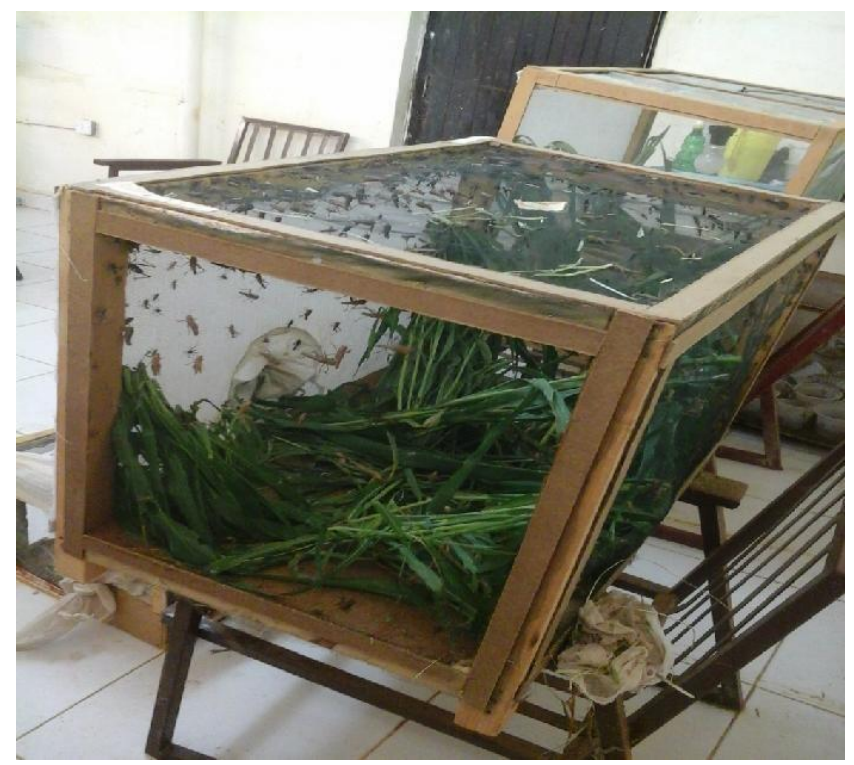

Figure 2. Migratory locust hopper's rearing cage 


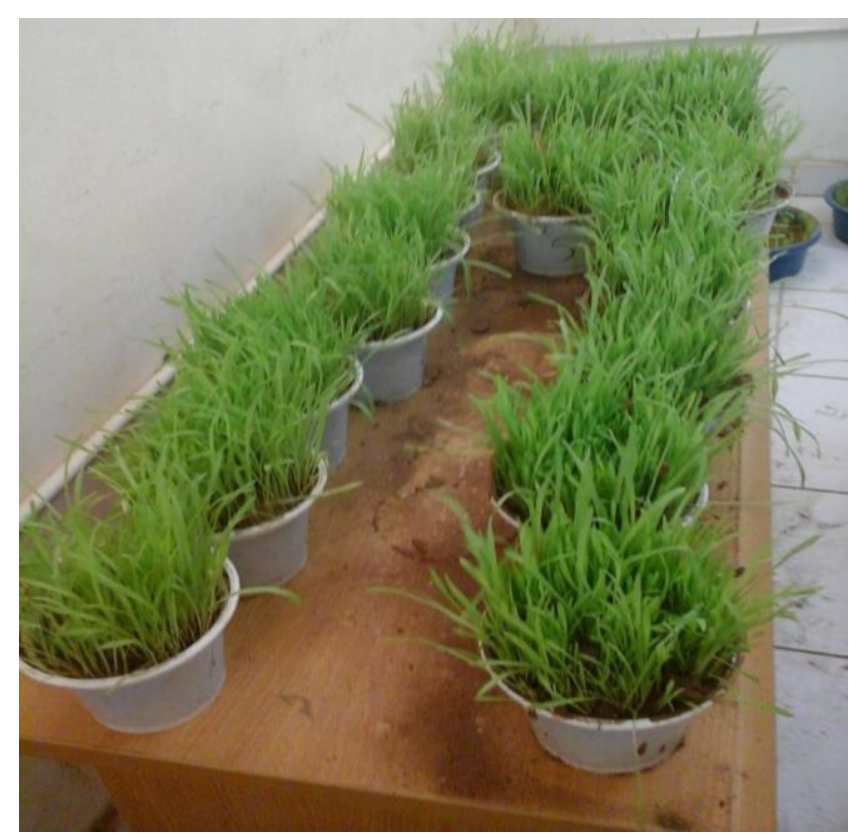

Figure 3. Millet seedlings grown in plastic cups and used to feed adults and nymphs.

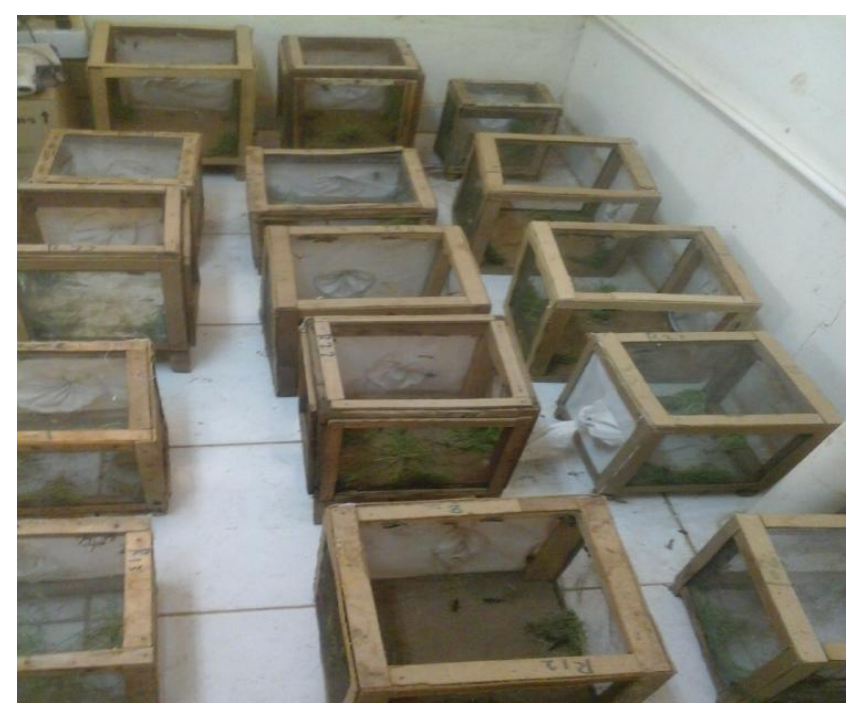

Figure 4. Experimental cages

\section{RESULTS AND DISCUSSION}

\section{Food preference (Feeding tests)}

The results of all treatments indicated significant difference in the susceptibility of ecotypes. The result presented in Table 1 and Figure 5 showed a significant difference in the susceptibility of five pearl millet ecotypes. The preference of ecotypes by nymphs increased as the time of observation increased.

The highly susceptible variety was Bayouda-cold resistant (V5) compared to four other ecotypes of treatments. The others were Kano-late maturing (V3), Wad elahow-late maturing (V4), Bayouda-early maturing (V2) and Dembi-short maturing (V1), respectively.
Table 1: Amount of food-intake (in gram) by the migratory locust nymphs

\begin{tabular}{lccccc}
\hline Ecotype & 24hrs & 48hrs & 72hrs & Mean & SE \pm \\
\hline V1 & $16.90 \pm 0.44$ & $17.93 \pm 0.79$ & $18.15 \pm 1.52$ & 17.66 & 0.92 \\
V2 & $16.69 \pm 0.24$ & $17.49 \pm 0.49$ & $18.42 \pm 0.88$ & 17.54 & 0.64 \\
V3 & $17.29 \pm 1.18$ & $18.20 \pm 0.36$ & $18.27 \pm 0.28$ & 17.92 & 0.61 \\
V4 & $16.48 \pm 0.67$ & $18.29 \pm 0.84$ & $18.54 \pm 0.65$ & 17.77 & 0.72 \\
V5 & $17.82 \pm 0.78$ & $18.19 \pm 1.26$ & $18.46 \pm 0.40$ & 18.15 & 0.81 \\
Mean & 17.04 & 18.02 & 18.37 & 17.81 & 0.74 \\
\hline
\end{tabular}

Note: V1: Dembi-short maturing, V2: Bayouda-early maturing, V3: Kano-late maturing, V4: Wad elahow-late maturing and V5: Bayouda-cold resistant

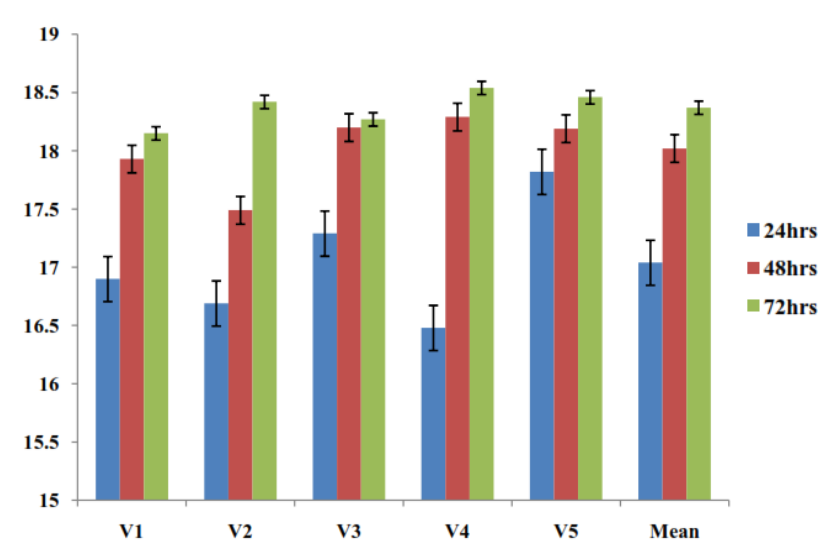

Figure 5. Food-intake in gram of the 5 test varieties by the $3^{\text {rd }}$ and $4^{\text {th }}$ migratory locust nymphs. Note: V1: Dembi, V2: Bayoudaearly, V3: Kano-late, V4: Wad elahowV5: Bayouda-late.

\section{Percentage of food intake by migratory locust hoppers on the five millet ecotypes.}

The percentages of five pearl millet ecotypes intake by hoppers of migratory locust are presented in Table 2 and Figure 6. There was clear significant difference among the five ecotypes. The highest percentage was recorded in Bayouda-cold resistant V5 ecotype (90.4\%), next is Wad elahow-late maturing V4 ecotype (89.4\%), followed by Kano-late maturing V3 ecotype (89.3\%), then Dembi-short maturing V1 ecotype (89.3\%) and Dembi-short maturing V2 ecotype (87.8\%). During the experiments, it was noticed that the preference of ecotypes V1 and V5 after the second day, the percentage of food intake was similar. However, the percentage of food-intake of ecotype V5 was highest on the first and third day of experiments.

\section{Weight of ingested food}

Table 2 and Figure 7 show clear variation in amount of food consumption of five ecotypes with $3^{\text {rd }}$ and $4^{\text {th }}$ instars of migratory locust. The variations were $17.5 \mathrm{~g}$ in Kano ecotype, $17.48 \mathrm{~g}$ in Wad elahow ecotype, $17.24 \mathrm{~g}$ in Bayouda-early ecotype, $17.12 \mathrm{~g}$ in Bayouda-late ecotype and $17.04 \mathrm{~g}$ in Dembi ecotype. The lowest amount of food ingested in the experiment was $17.04 \mathrm{~g}$ in Dembi ecotype variety, and the highest amount ingested of food taken by hoppers, compared with other four ecotype varieties of pearl millet was $17.5 \mathrm{~g}$ in Kano ecotype. 
Table 2: Food intake by Migratory locust hoppers of the five millet ecotypes

\begin{tabular}{lcccc}
\hline Ecotype & 24hrs & 48hrs & 72hrs & Mean \\
\hline V1 & $88.5 \%$ & $90.5 \%$ & $89.1 \%$ & $89.3 \%$ \\
V2 & $88.1 \%$ & $86.6 \%$ & $88.7 \%$ & $87.8 \%$ \\
V3 & $89.2 \%$ & $90.2 \%$ & $88.6 \%$ & $89.3 \%$ \\
V4 & $90.4 \%$ & $88.2 \%$ & $89.5 \%$ & $89.4 \%$ \\
V5 & $90.8 \%$ & $90.4 \%$ & $90 \%$ & $90.4 \%$ \\
Mean & $89.4 \%$ & $89.1 \%$ & $89.2 \%$ & $89.2 \%$ \\
\hline
\end{tabular}

Note: V1: Dembi-short maturing, V2: Bayouda-early maturing, V3: Kano-late maturing, V4: Wad elahow-late maturing and V5: Bayouda-cold resistant

Table 3: Weight of ingested food in grams

\begin{tabular}{lccccc}
\hline Ecotype & 24hrs & 48hrs & 72hrs & Mean & SE \pm \\
\hline V1 & $16.89 \pm 2.60$ & $17.41 \pm 1.21$ & $16.83 \pm 1.05$ & $17.04 \mathrm{~g}$ & 1.62 \\
V2 & $17.40 \pm 1.69$ & $17.1 \pm 1.05$ & $17.23 \pm 1.29$ & $17.24 \mathrm{~g}$ & 1.34 \\
V3 & $16.72 \pm 0.95$ & $17.65 \pm 2.66$ & $18.12 \pm 0.34$ & $17.5 \mathrm{~g}$ & 1.32 \\
V4 & $17.07 \pm 1.89$ & $17.61 \pm 3.47$ & $17.75 \pm 0.46$ & $17.48 \mathrm{~g}$ & 0.86 \\
V5 & $16.71 \pm 0.68$ & $16.9 \pm 1.14$ & $17.76 \pm 0.79$ & $17.12 \mathrm{~g}$ & 0.87 \\
Mean & 16.96 & 17.33 & 17.54 & $17.28 \mathrm{~g}$ & 1.2 \\
\hline
\end{tabular}

Note: V1: Dembi-short maturing, V2: Bayouda-early maturing, V3: Kano-late maturing, V4: Wad elahow-late maturing and V5: Bayouda-cold resistant.

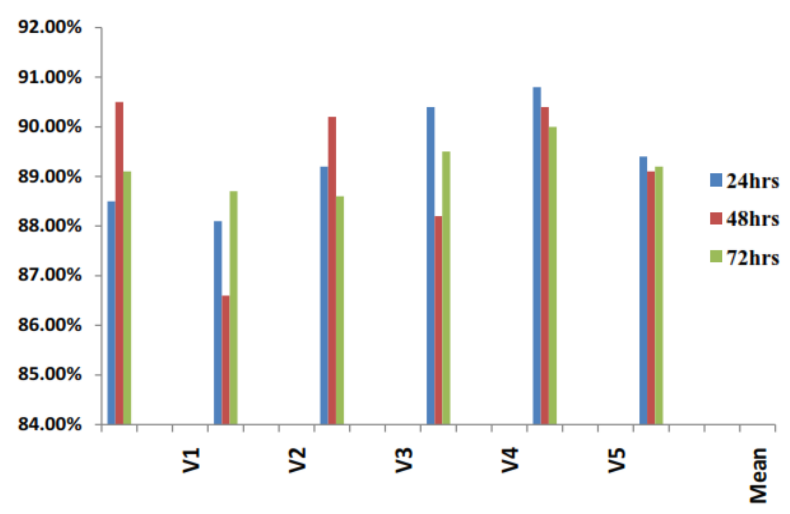

Figure 6. Percentage of Ecotypes preference or food intake by Migratory locust hoppers. Note: V1: Dembi, V2: Bayouda-early, V3: Kano-late, V4: Wad elahow, V5: Bayouda-late.

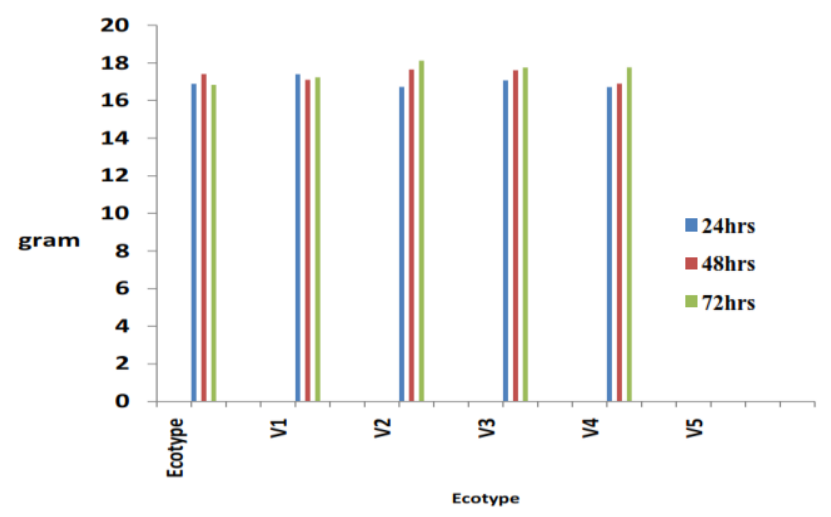

Figure 7. The weight of food ingested. Note: V1: Dembi-short maturing, V2: Bayouda-early maturing, V3: Kano-late maturing, V4: Wad elahow-late maturing and V5: Bayouda-cold resistant.

\section{Percentage of ingested food}

Table 4 and Figure 8 show the different percentages of amount of ingested food of five ecotypes of pearl millet Pennisetum glaucum variety, by $3^{\text {rd }}$ and $4^{\text {th }}$ instars of migratory locust. The difference percentage was $98.2 \%$ in Wad elahow ecotype (V4), 97.3\% in Bayouda-late ecotype (V5), $96.7 \%$ in Kano ecotype (V3), 96.5\% in Dembi ecotype (V1) and $96.1 \%$ in Bayouda-early ecotype (V2) respectively.

\section{Weight of feces in grams}

Table 5 and Figure 9 show the susceptibility of five ecotypes of pearl millet, according to remains of feces in any ecotype variety. The least amount of feces was $0.28 \mathrm{~g}$ in ecotype (V5) Bayouda late. This means that a large part of the food taken was ingested, digested and assimilated in comparison with the other four ecotypes. The different percentages of ingested food consumption of the five ecotypes, by $3^{\text {rd }}$ and $4^{\text {th }}$ instars of migratory locust, execrated feces ranked $0.47 \mathrm{~g}$ in Bayouda-early ecotype (V2), $0.66 \mathrm{~g}$ in Dembi ecotype (V1), $0.67 \mathrm{~g}$ in Wad elahow ecotype (V4) and $0.68 \mathrm{~g}$ in Kano ecotype (V3) respectively.

\section{Discussion}

Sudan is one of the countries whose national income relies heavily on agricultural commodities and natural resources. Pearl millet, Pennisetum glaucum is an agricultural commodity that represents the staple cereal of many millions of the world's poorest people in the semiarid regions of tropical and subtropical developing countries in Asia and Africa.

Table 4: Percentage of ingested food.

\begin{tabular}{lllll}
\hline Ecotype & 24hrs & 48hrs & 72hrs & Mean \\
\hline V1 & $95.4 \%$ & $97.2 \%$ & $97.1 \%$ & $96.5 \%$ \\
V2 & $97.2 \%$ & $95.1 \%$ & $96.1 \%$ & $96.1 \%$ \\
V3 & $96.3 \%$ & $95.3 \%$ & $98.5 \%$ & $96.7 \%$ \\
V4 & $96.9 \%$ & $99.5 \%$ & $98.2 \%$ & $98.2 \%$ \\
V5 & $98.1 \%$ & $94.9 \%$ & $98.8 \%$ & $97.3 \%$ \\
Mean & $96.8 \%$ & $96.4 \%$ & $97.8 \%$ & $97 \%$ \\
\hline
\end{tabular}

Note: V1: Dembi-short maturing, V2: Bayouda-early maturing, V3: Kano-late maturing, V4: Wad elahow-late maturing and V5: Bayouda-cold resistant

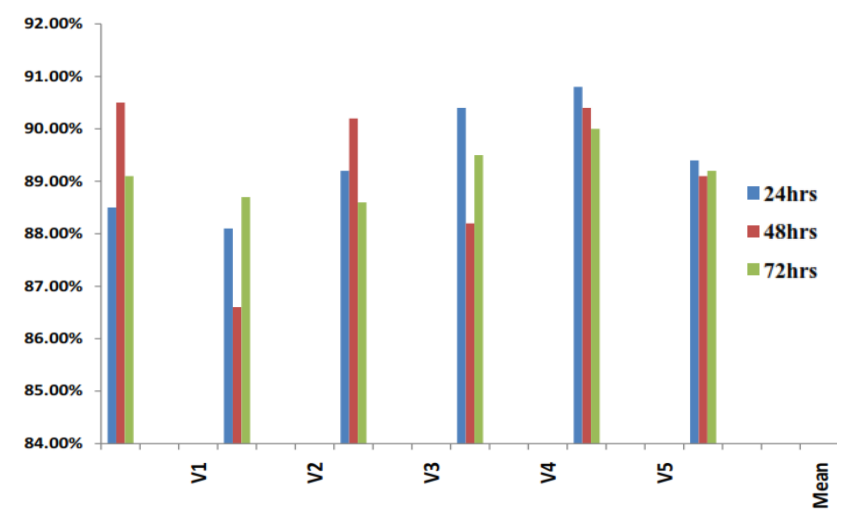

Figure 8: Percentage of ingested food. Note: V1: Dembi-short maturing, V2: Bayouda-early maturing, V3: Kano-late maturing, V4: Wad elahow-late maturing and V5: Bayouda-cold resistant. 


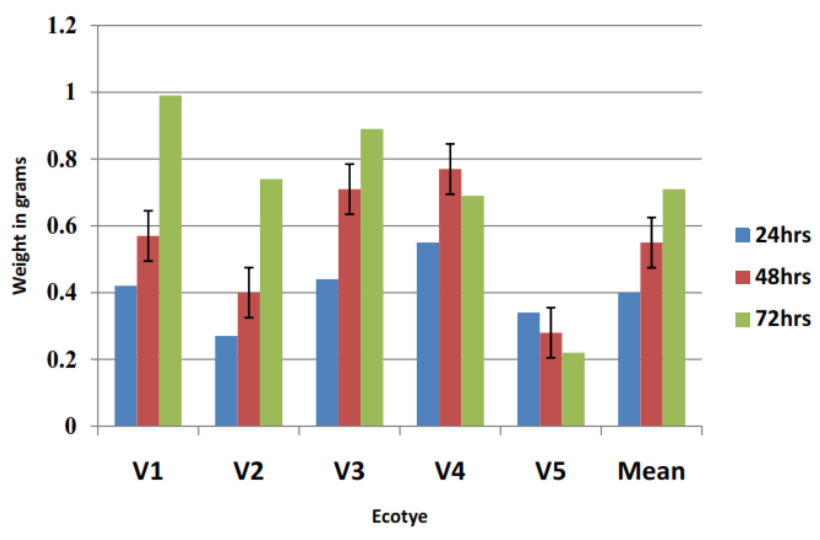

Figure 9. The weight of feces in gram. Note: V1: Dembi-short maturing, V2: Bayouda-early maturing, V3: Kano-late maturing, V4: Wad elahow-late maturing and V5: Bayouda-cold resistant

In Sudan, the pearl millet (Dukhun) is mainly grown in the western parts of Sudan (Darfur and Kordofan states) and also in eastern the region, Red Sea, Kassala, and the Gedaref States. Pearl millet in these areas is frequently attacked by locusts. Among these, it was found that the African migratory locust Locusta migratoria migratorioides is considered a devastating pest on pearl millet through its ability to form dense aggregations of nymphs (hoppers) and highly mobile aggregations of adults (swarms) that feed on various graminaceous crops (Sorghum and Millet). Since the migratory locust is a primary threat to these crops and resources, its outbreaks are severely followed and a prompt of control measures. So, the possibility of managing the African migratory locust on Pearl millet is by planting resistant cultivars prevailed.

The present work was conducted to investigate the susceptibility of five pearl millet varieties (ecotypes) to infestation by the $3^{\text {rd }}$ and $4^{\text {th }}$ nymphal instars of the species. According to the results of the study, it was evident that all five ecotype varieties of pearl millet were palatable to the migratory locust $3^{\text {rd }}$ and $4^{\text {th }}$ nymphal instars. These results, in general, were similar to the results of pearl millet pests inventoried by Kamal et al. (2013) who found that pearl millet was infested by many pests, such as the larvae of Spodoptera sp, locusts (Schistocerca gregaria and Locusta migratoria migratorioides). The results showed that there was variation in infestation rate in the five ecotypes. This finding was in agreement with Siddig et al. (2013) who stated that different varieties of pearl millet reflect varying levels of susceptibility and resistance to pests.

From the results of this study, it was noticed that the nymphs and adults of African migratory locust prefer the vegetation shoots of pearl millet to bran and grains. This result is in agreement with Sharma et al. (1996) who mentioned that nymphs and adults of the African migratory locust occasionally attack all stages of the pearl millet causing heavy damage during outbreaks but, prefer to feed on leaves, flowers, and developing grain.

According to the result in Table 1 and Figure 5, the susceptibility and food preference on the five varieties by the $3^{\text {rd }}$ and $4^{\text {th }}$ nymphal instars of the African migratory locust was high on Bayouda-Late maturing, Kano-late maturing, Wad elahow-late maturing, Bayouda-early maturing and Dembi-early maturing successively and in descending order. Also, these results are confirmed the amount of food intake (in grams) as in Table 2 and Figure 6.

The results on the amount of feces excreted by the hoppers in Table 5 and histogram in Figure 9 indicated that there was significant difference at $1 \%$ level, among remain of feces of any ecotype variety and application period. It was found that the percentage of taken and ingested food was $86.4 \%$. Of the assimilated food from total ingested was $97 \%$ and only $3 \%$ was excreted in feces. These results were in line with Sharma and Davies (1988) who showed that the locust hoppers and bands are particularly devastating and invade millet in Sudan. It is also in agreement with result stated by Niassy et al. (2011) who mentioned that the late instars and adults cause economic damage directly to pasture and crops such as millet. Moreover, Latchininsky (2013) confirmed that the African migratory locust has the largest distribution among all grasshoppers and locusts but, the ecological requirements of the migratory locust are quite narrow, and the devastating damage caused by hopper bands and swarms are primarily restricted to grasses, millet, and others.

From the results in Tables 1, 2, 3 and Figures 5, 6, 7, it is noticed that the most susceptible ecotype was Bayoudaearly, Bayouda-late, Wad elahow, Kano and the least susceptible was Dembi-early. In theory, Abuelgasim (1989), Sabil (1991) and Abuelgasim (2011) mentioned that early Bayouda is grown in cracked clay soil in Jebal Mara, late Bayouda is grown in cracked clay soil in Kabkabia, Wad elahow is grown in south of Nyala semi cracking clay soil, Kano is grown in cracking loamy clay soil south-west of Nyala and Dembi is grown in mixed sandy clay soil. This was confirmed by Guichard (1955), SEA (1990), who mentioned that the locust prefers to live in black cracking clay land and boundary lands of savannah, which means that its feed behavioral preferring plants grow in similar environmental areas, although there are differences in the condition. Where the varieties are cultivated of the location where the study is made, there was no difference regarding susceptibility of the five varieties to the insect pest.

In conclusion, the results showed significant difference in the susceptibility of five varieties of ecotype of pearl millet. The preference and susceptibility of ecotypes by nymphs were increasing with the increase of application time. The highest percentages of ingested food in the five ecotypes of pearl millet Pennisetum glaucum variety, with $3^{\text {rd }}$ and 4th instars of African migratory locust, was in Bayouda-late maturing. Further testing of different graminaceous species on different nymphs of African migratory locust is needed. Further research works on evaluation of food preference and susceptibility of infestations of pearl millet varieties with other pests, is recommended. 


\section{REFERENCES}

Abuelgasim HE. 1989. Millet breeding in the Sudan past, present, and future. Proceedings of ARC / INTSORMIL sorghum and millet Workshop. October-28-November 2, 1989, Wad Medani, Sudan.

Abuelgasim HE. 2011. Pearl millet (Pennisetum glaucum) production and improvement in Sudan. Sudanese Encyclopedia of Agricultural, Khartoum.

Adekunle AA. 2012. Agricultural innovation in sub-Saharan Africa: experiences from multiple stakeholders. Approaches. Forum for Agricultural Research in Africa, Ghana.

Anonymous. 1966. The Locust Handbook. Anti-Locust Research Centre, London.

Devi PB, Vijayabharathi R, Sathyabama S, Malleshi NG, Priyadarisini VB. 2011. Health benefits of finger millet (Eleusine coracana L.) polyphenols and dietary fiber: a review. J Food Sci Technol 51 (6) 1021-1040. DOI: 10.1007/s13197-011-0584-9

Fan YZ. 1983. Locust outbreaks in the shany dynasty. Agric Archaeol 2 314-317.

FAO. 2009. Food and Agriculture Organization of the United Nations Evaluation of Field trial data on the effectiveness of insecticides against Locusts and Grasshoppers. Report of Pesticides Referee Group in Rome, Italy.

Gomez KA, Gomez AA. 1984. Complete randomized design. In Statistical Procedures for Agricultural Research. John Willey and Sons, New York.

Guichard K. 1955. Habitats of the desert locust (Schistocerca gregaria Forskal). Anti-Locust Bull 21: 1-33.

Guo F, Chan YL, Lu BL. 1991. The biology of the migratory locusts In China. Shandong Science and Technology Press, Shandong, China 591 pp. Book Review. Environ Entomol 22 (2): 498. DOI: 10.1093/ee/22.2.498a

Hamid BH. 2003. Overview of sorghum and millet in Sudan. Marketing Management \& Head Socio-Economic Studies Section Ministry of Science and Technology Agricultural Research Corporation Food Research Centre, Sudan.

Kamal IA, Siddig AMA, Ali HB, Thabit AH. 2013. Effect of plant spacing and variety on performance of rain-fed pearl mille (Pennisetum glaucum L.) grown on two soil types at Zalingei Area, Sudan. ARPN J Sci Technol 3 (5): 512-517.

Kumar RK, Ramamurthy VV. 2009. Tropical outbreak of migratory locust, Locusta migratoria migratorioides (Reich and Fairmaire) in Lakakh valley of J and K. Biol Forum Intl J 1: 89-97.
Latchininsky AV. 2013. Locusts and remote sensing a review. J Appl Rem Sens 7: 1-32. DOI: 10.1117/1.JRS.7.075099

Meinzingen WF. 1993. A Guide to migrant Pest Management in Africa Food and Agriculture Organization of United Nations (FAO). General Printers Ltd. Nairobi.

Niassy S, Diarra K, Ndiaye S, Niassy A. 2011. Pathogenicity of local Metarhizium anisopliae var. acridum strains on Locusta migratoria migratorioides Reiche and Farmaire and Zonocerus variegates Linnaeus in Senegal. Afr J Biotechnol 10 (1): 28-33.

Obilana AB, Millets ME. 2002. Pseudocereals and Less Common Cereals: Grain Properties and Utilization Potential. Springer-Verlag, Berlin. DOI: 10.1007/978-3-662-09544-7_6

Sabil AH. 1991. Environmental Constraints to pearl millet Production in North Dar Fur, Sudan. [Thesis]. University of Reading, U.K.

SEA. 1990. Supplemental Environmental Assessment for United States Agency for International Development. Funding of Locust and Grasshopper pesticide usage in Sudan. USAID, Khartoum.

Sharma HC, Faujdar S, Nwanze KF. 1996. Plant resistance to insects in sorghum. International Crops Research Institute for the Semi-Arid Tropics, Khartoum.

Sharma HC, Davies JC. 1988. Insect and Other Animal Pests of Millets. ICRISAT. International Crops Research Institute for the Semi-Arid Tropics. India.

Siddig AMA, Kamal IA, Ali HB, Thabit AH. 2013. Effect of sowing date and variety on growth and yield of pearl millet Pennisetum glaucum L.) grown on two soil types under rain-fed conditions at Zalingei Area in Sudan. ARPN J Sci Technol 3 (4): 340-344.

Steedman A. 1988. Locust Handbook (2 ${ }^{\text {nd }}$ ed.). Overseas. Development Natural Resources Institute, London.

Uvarov BP. 1921. A revision of the genus Locusta, L (= Pachytylus, Fieb). with new theory, as to the periodicity and migrations of locusts. Bull ENT Res 12: 135-163. DOI: 10.1017/S0007485300044989

Uvarov BP. 1966. Grasshoppers and Locust. A handbook of general acridology. Volume 1. Cambridge University Press for Anti-Locust Research Center, UK.

Uvarov B. 1977. Grasshoppers and Locusts a handbook on General Acridology. Centre Overseas Pest Res 2: 613.

Yang X, Wan Z, Perry L, Lu H, Wang Q, Hao C, Li J, Xie F, Yu J, Cui T, Wang T, Li M, Ge QH. 2012. Early millet use in northern China. Proc Nat Acad Sci 109 (10): 3726-3730. DOI: 10.1073/pnas.1115430109

Zhang DX, Yan LN, Ji YJ, Hewitt GM, Huany ZS. 2009. Unexpected Relationships of sub structured population in Chinese locust migratory. Biology 9: 144. DOI: 10.1186/1471-2148-9-144 